\title{
Insights into Enchondroma, Enchondromatosis and the risk of secondary Chondrosarcoma. Review of the literature with an emphasis on the clinical behaviour, radiology, malignant transformation and the follow up
}

\author{
Minireview
}

G. W. HERGET ${ }^{1, \star}$, P. STROHM ${ }^{2}$, C. ROTTENBURGER ${ }^{3}$, U. KONTNY ${ }^{4}$, T. KRAUSS ${ }^{5}$, J. BOHM ${ }^{6}$, N. SUDKAMP ${ }^{7}$, M. UHL ${ }^{8}$

${ }^{1}$ Department of Orthopaedics and Traumatology / Comprehensive Cancer Centre Freiburg, University Medical Centre Freiburg, Freiburg i. Br., Germany; ${ }^{2}$ Department of Orthopaedics and Traumatology, University Medical Centre Freiburg, Freiburg i. Br., Germany; ${ }^{3}$ Clinic for Radiology and Nuclear Medicine, Department for Nuclear Medicine, University Hospitaol Basle, Basle, Switzerland; ${ }^{4}$ Children's Hospital, Division of Pediatric Hematology and Oncology, University Medical Centre Freiburg, Freiburg, Germany; ${ }^{5}$ Department of Radiology, University Medical Centre Freiburg, Freiburg i. Br, Germany; ${ }^{6}$ Institute of Pathology, University Medical Centre Aachen, Aachen, Germany; ${ }^{7}$ Department of Orthopaedics and Traumatology, University Medical Centre Freiburg, Freiburg i. Br., Germany; ${ }^{8}$ Department of Radiology, St. Josefshospital Freiburg, Freiburg i. Br., Germany

*Correspondence: georg.herget@uniklinik-freiburg.de

Received August 7, 2013 / Accepted September 10, 2013

\begin{abstract}
The Enchondroma is a common, benign, cartilage forming tumour. They usually occur as a single, asymptomatic lesion. Occasionally patients present with multiple enchondromas which is generally defined as enchondromatosis. This entity encompasses several different subtypes including Ollier disease and Maffucci syndrome (enchondromatosis associated with soft tissue haemangiomas) as the most commons. Some of them have a complicated clinical course when malignant transformation occurs. This malignant progression is a well known fact especially in enchondromatosis, but up to now there is still a lack of recommendations concerning the follow up. The aim of this article is to review the clinical and imaging features of patients with solitary enchondroma and enchondromatosis focusing on the development of secondary chondrosarcoma and the follow up.
\end{abstract}

Key words: enchondroma, enchondromatosis, Maffucci syndrome, Morbus Ollier, secondary chondrosarcoma, follow up

Enchondromas are common, benign, and usually asymptomatic hyaline cartilage forming tumors mostly located in the meta- and diaphysis, seldom in the epiphysis of the short and long tubular bones of the limbs (Figure 1) [1, 2, 3]. They usually occur as a single lesion (solitary enchondroma) and are most often found incidentally when radiographic studies are performed for other reasons [3]. In a Mayo Clinic study (en)chondromas constituted $15.6 \%$ of benign bone tumors and $4.7 \%$ of all tumors, however this do not reflect the true incidence since most of enchondromas are asymptomatic [4].

Occasionally patients present with multiple enchondromas. This is generally defined as enchondromatosis [5]. Its prevalence is estimated to be one in 100.000 [6]. The disorder manifests in early childhood without any significant gender bias [5].
Enchondromatosis encompasses several different subtypes of which Ollier disease (enchondromatosis) (Figure 2) and Maffucci syndrome (enchondromatosis associated with soft tissue haemangiomas) (Figure 3) are most common [7, 8]. Other subtypes such as metachondromatosis, genochondromatosis, spondyloenchondrodysplasia, dysspondyloenchondromatosis and cheirospondyloenchondromatosis are rare [5, 7]. Most subtypes are non-hereditary, while some are autosomal dominant or recessive [5]. Clinically, the bone deformities as well as malignant progression of enchondromas may require (multiple) surgical interventions [9-13].

The true rate of malignant transformation in solitary enchondroma is not known as most of the enchondromas are asymptomatic and go undetected. Not considering the selec- 


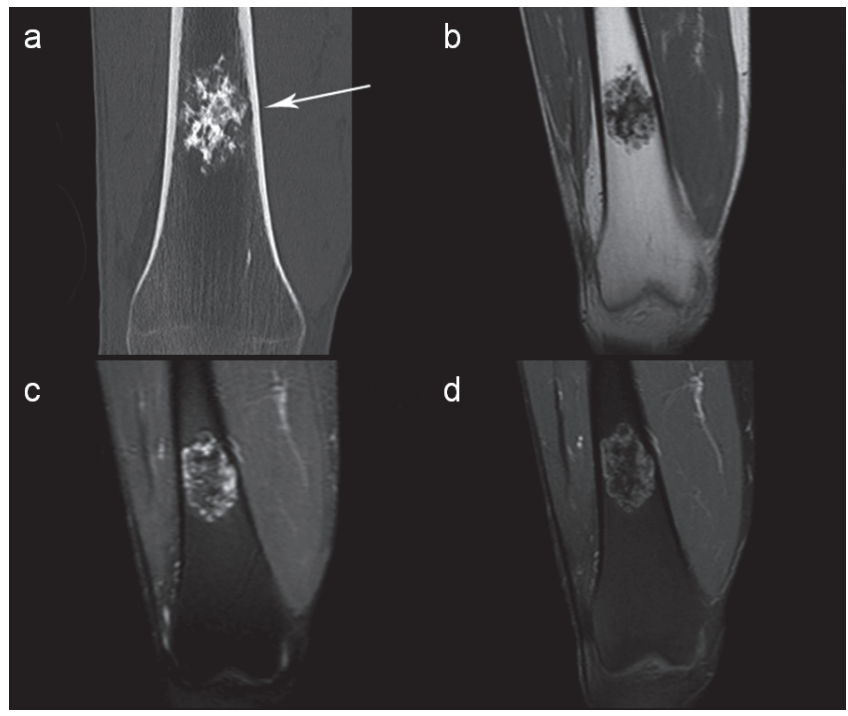

Figure 1 (a-d). 62-year-old man with incidental enchondroma in distal femoral diaphysis, initially seen on routine MRI of the right knee. a: Computed tomography of the right femur shows punctuate chondroid calcifications located centrally within the distal femoral diaphysis. There is minimal endosteal scalloping of the surrounding cortex (arrow). b: Coronal T1-weighted (TR/TE, 765/11) MR image shows circumscribed area of marrow replacement with low-intermediate signal intensity (SI). Coronal TIRM (C, TR/TE, 4,780/29) MR image demonstrates a lobulated endosteal lesion with high SI. Some intralesional areas of low SI located within the lesion are the chondroid matrix. No perilesional bone marrow edema is seen. d: Fat-suppressed, gadolinium-enhanced T1-weighted (TR/TE, 622/11) image shows a mild peripheral and septal "ring-and-arc" pattern of contrast enhancement of the lesion.

tion bias, the risk of developing a secondary chondrosarcoma in solitary enchondroma described to be up to $4 \%$ [10]. It is estimated that primary Chondrosarcoma is approximately two times more common than CS arising from a solitary enchondroma [14].

Of all patients diagnosed with Ollier disease, malignant transformation is believed to occur in $10-20 \%$ [14] and a recent study recorded the development of one or more chondrosarcomas in $40 \%$ of patients with Ollier diseases and Maffucci syndrome, respectively [15].

Most of the patients with malignant transformation complained of pain as the leading symptom, but there were also patients without any pain [16-18]. Furthermore, some of the patients with an enchondroma are also suffering from pain, which by itself by no means eliminates the benign enchondroma from consideration [16].

This knowledge of malignant progression of the enchondroma(tosis) motivates the desire for a definition of a follow up treatment. Until now, one does not exist.

For that a systematic review of the literature was conducted for selected articles published from January 1980 to December 2011. Searching was performed using a full-text electronic journal database (Pubmed). The terms 'enchondroma', 'enchondromatosis', 'Maffucci syndrome', 'chondrosarcoma' and

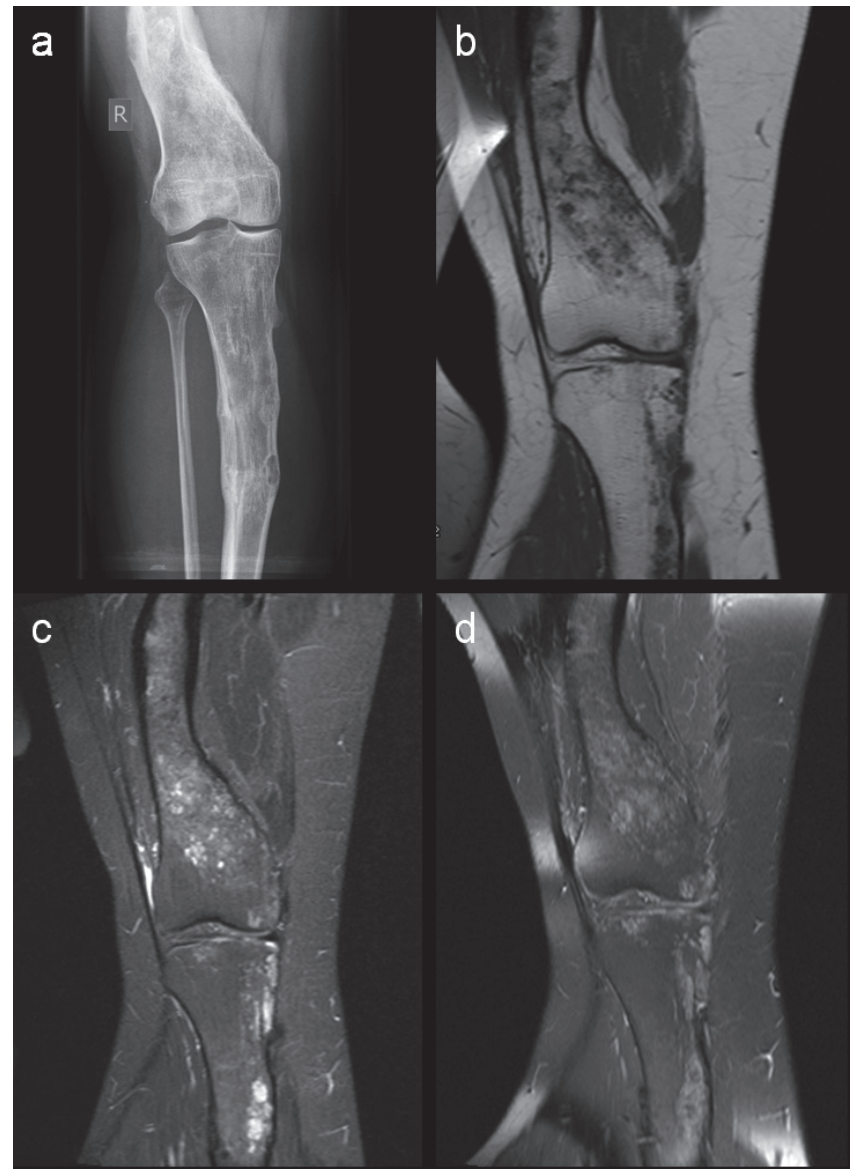

Figure 2 (a-d): 33 -year-old woman suffering from Ollier disease. a: Plain film radiography shows a deformation of the right femur and tibia. Multiple enchondromas are localized in the right leg. There is an endosteal scalloping with thinning of the cortex, particularly in the tibial diaphysis. MRI demonstrates multiple enchondromas with low SI on coronal T1-weighted image (B, TR/TE, 700/17) and high SI on coronal TIRM images $(C, T R / T E, 5,210 / 55)$. On fat-suppressed, gadolinium-enhanced T1-weighted images (D, TR/TE, 541/17) a mild contrast enhancement of the lesions can be seen. NB: Biopsies taken from the distal Femur as well as the proximal tibia showed no signs o malignancy.

'secondary chondrosarcoma' were MeSH (Medical Subheading) terms and the search sets were restricted to humans.

The characteristics of patients with secondary chondrosarcoma were evaluated including (a) age at onset of secondary malignancy, (b) interval between diagnosis of benign enchondroma (including enchondromatosis) and time point of malignant progression, (c) localisation of the secondary chondrosarcoma and (d) clinical symptoms. Furthermore typical radiographical characteristics of enchondroma and secondary chondrosarcoma are described.

Following these literature data a proposal for follow up of patients with solitary enchondroma and enchondromatosis of the axial skeleton and the long bones are made.

Clinical presentation. In our literature review the age of patients with secondary chondrosarcoma (sCS) arising from 
a pre-existing enchondroma ranged from 31 years to 80 years. The age of patients with a sCS with an underlying enchondromatosis/Maffucci syndrome ranged from 10 to 69 years (Table 1). Summarizing, the average age of patients with an underlying enchondromatosis was about 10 - 15 years younger than these with a primary chondrosarcoma (with an average age about 52 years $[1,2,3]$.

The risk of development of secondary chondrosarcoma in solitary enchondroma was up to $4.2 \%$ (Table 1). Malignant transformation in enchondromatosis is estimated to occur in $25-30 \%$ of the patients $[2,20]$, in a recent study up to $40 \%$ [15]. In our reported literature it was between $20 \%$ and $45.8 \%$ in pre-existing enchondromatosis, and ranged between $52 \%$ and $57.1 \%$ in patients with a Maffucci syndrome (Table 1).

Overall, the time between the initial diagnosis of a preexisting (benign) enchondroma (including an enchondroma in enchondromatosis) and the diagnosis of malignancy was between 6 months and up to 30 years (Table 1), in a study by Schwartz et al. the interval was even up to 54 years [23]. However, these data were badly reported in most studies compared to stating the age of patients at transformation.

In most cases of malignant transformation to secondary chondrosarcoma the patient suffered from pain $[4,10,14$, 19-22, 24, 26-28]. It has been reported that in patients with low grade chondrosarcoma $43 \%$ - $60 \%$ have night pain or rest pain, $21 \%$ have vague regional pain, and $19 \%$ had lesions that were detected incidentally $[27,28]$ People with higher grade tumors (grade II or III chondrosarcoma) have pain up to $80 \%$ of the time [28]. In another publication it was stated out that $97 \%$ of the patients with a secondary chondrosarcoma have pain [21]. Interestingly, as for the other chondrosarcomas, the delay between the first clinical signs and the diagnosis was often long, two to four years depending on the studies [22]. In some cases the malignant transformation became evident only during radiographic follow up (Table 1) [20,22]

A palpable mass was detected in a very few cases. This is ascribed to the fact that the transformation occurs in a primarily intramedullary located lesion [27-30]. Rarely, people will discover they have a chondrosarcoma when they develop a fracture through the tumor [21, 27-30]. However, some of the patients with an enchondroma are also suffering from pain [30]. Therefore, pain in and of itself by no means eliminates the totally benign enchondroma from consideration. And, secondary chondrosarcomas could be radiological discoveries without any clinical symptoms [16].

Malignant transformation in solitary enchondroma and enchondromatosis (Ollier disease, Maffucci syndrome) preferentially affects the long bones of the lower limb, particularly the femur; other frequently involved sites are the pelvis, the humerus, scapula, ribs and the tibia (Table 1). Plurifocal malignant transformation is not unusual and is always reported for patients with Ollier disease or Maffucci syndrome [23, 31]. Further on, patients suffering enchondromatosis seems to be at a higher risk for primary brain tumors [32].

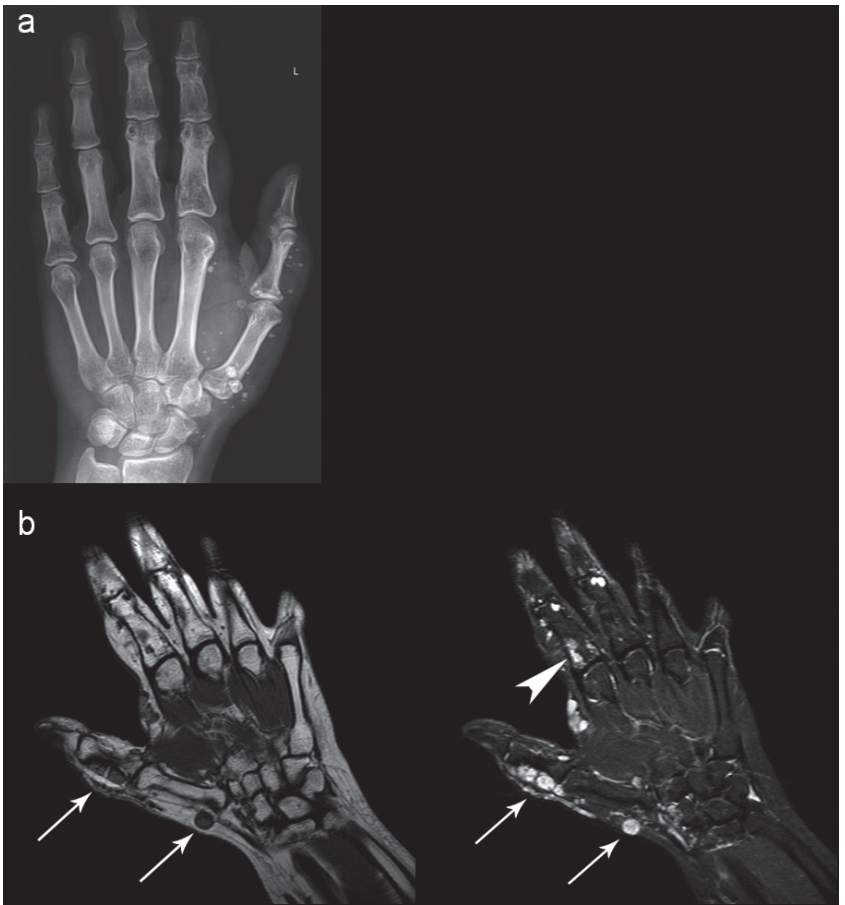

Figure 3 (a-c): 35-year-old woman suffering from Maffucci syndrome, diagnosed at the age of 3 years. a: Radiography shows enchondromas and multiple soft tissue phleboliths of the left hand. b, c: MRI demonstrates multiple soft-tissue masses representing hemangiomas that have low SI on T1-weighted (B, TR/TE, 653/24) and high SI on STIR (C, TR/TE, 4,660/45) images (arrow). Enchondromas with high SI on STIR-images are localized in the phalanges of the left hand (arrowhead).

Genetics. The exact cause of enchondromatosis is unknown. Most cases of enchondromatosis are sporadic, but families with multiple affected members have been reported, possibly suggesting autosomal dominant inheritance $[5,33]$. Alternatively, a random spontaneous mutation is hypothesized. This might occur in early development, in mesoderm, therefore generating a mosaicism $[2,33]$.

It is speculated that a heterozygous PTHR1 mutation is likely to contribute to Ollier disease in a small subset of patients [34]. Enchondromas are usually in close proximity to, or in continuity with, growth-plate cartilage. Consequently, they may result from abnormal regulation of proliferation and terminal differentiation of chondrocytes in the adjoining growth plate [34]. In normal growth plates, differentiation of proliferative chondrocytes to post-mitotic hypertrophic chondrocytes is regulated in part by a tightly coupled signalling relay involving parathyroid hormone related protein (PTHrP) and Indian hedgehog (IHH) [34]. PTHrP delays the hypertrophic differentiation of proliferating chondrocytes, whereas IHH promotes chondrocyte proliferation [34]. Hopyan et al. identified a mutant PTH/PTHrP type I receptor (PTHR1) in human enchondromatosis that signals abnormally in vitro and causes enchondroma-like lesions in transgenic mice [35]. 
Table 1. Series on secondary chondrosarcoma (in alphabetical order)

\begin{tabular}{|c|c|c|c|c|c|c|}
\hline Author & $\begin{array}{l}\text { (Pre-existing) } \\
\text { Lesion } \\
\text { (No.) }\end{array}$ & $\begin{array}{l}\text { Secondary } \\
\text { chondrosarcoma } \\
\text { / Pre-existing } \\
\text { lesion } \\
\text { (No.) }\end{array}$ & $\begin{array}{l}\text { Age at the diagnosis } \\
\text { of secondary } \\
\text { chondrosarcoma }\end{array}$ & $\begin{array}{l}\text { Cinical presentation - } \\
\text { Symptoms of malignant } \\
\text { transformation }\end{array}$ & $\begin{array}{l}\text { Time of diagnosed } \\
\text { malignancy after } \\
\text { primary diagnosis } \\
\text { - follow up }\end{array}$ & $\begin{array}{l}\text { Localisation of } \\
\text { sCS }\end{array}$ \\
\hline Altay et al. [10] & $\begin{array}{l}143 \mathrm{SE} \\
1 \mathrm{ME} \\
1 \mathrm{MS} \\
\\
\text { [Total study group: } \\
627 \text { cartilage } \\
\text { tumors, } 331 \text { SO } \\
\text { and } 92 \mathrm{MO} \text { were } \\
\text { excluded] }\end{array}$ & $\begin{array}{l}6 \text { sCS in pre- } \\
\text { existing SE (4,2\%) } \\
2 \text { sCS in } 1 \text { patient } \\
\text { with pre-existing } \\
\text { ME } \\
3 \text { sCS in 1 patient } \\
\text { with pre-existing } \\
\text { Maffucci syndrom }\end{array}$ & $\begin{array}{l}\text { sCS (pre-existing SE): } \\
31 \text { - } 80 \text { years (median } \\
49.8 \text { years) } \\
\\
\text { sCS (pre-existing ME): } \\
24 \text { years } \\
\text { sCS (pre-existing MS): } \\
27 \text { years }\end{array}$ & Pain & $\begin{array}{l}\text { SE: } 4-14 \text { (median } \\
7,7 \text { years) } \\
\text { ME: } 10 \text { years } \\
\text { MS: } 14 \text { years }\end{array}$ & $\begin{array}{l}\text { Enchondroma- } \\
\text { group, (sCS } \\
\text { affected the hand } \\
\text { are excluded): } \\
\text { Femur proximal } \\
\text { (4), femur distal } \\
\text { (4), Os ilium (3), } \\
\text { humerus proximal } \\
\text { (3), scapula (2), } \\
\text { tibia (1) }\end{array}$ \\
\hline $\begin{array}{l}\text { Brien EW et al. } \\
\text { [14] }\end{array}$ & $\begin{array}{l}\text { Total study group: } \\
1200 \text { cartilage } \\
\text { tumors [ } 845 \\
\text { benign, } 356 \\
\text { malignant; } 39 \% \\
\text { of entire set of } \\
3067 \text { primary } \\
\text { bone tumors (BT) } \\
\text { studied } \\
20 \mathrm{ME}\end{array}$ & $\begin{array}{l}104 \text { sCS in } \\
\text { pre-existing SE } \\
(86 \text { sCS in pre- } \\
\text { existing SE } \rightarrow \text { sCS2 } \\
\text { and } 18 \text { sCS in pre- } \\
\text { existing SE } \rightarrow \text { sCS2 } \\
\rightarrow \text { dCS) } \\
4 \text { sCS in pre- } \\
\text { existing ME }(20 \%)\end{array}$ & $\begin{array}{l}\text { sCS2: } 52 \text { years (average } \\
\text { age) } \\
\text { dCS: } 70 \text { years (average } \\
\text { age) } \\
\text { sCS (pre-existing ME): } \\
27 \text { years (average age) } \\
\text { dCS (pre-existing } \\
\text { ME): } 45 \text { years (average } \\
\text { age) } \\
- \\
\text { No data on sex } \\
\text { distribution }\end{array}$ & 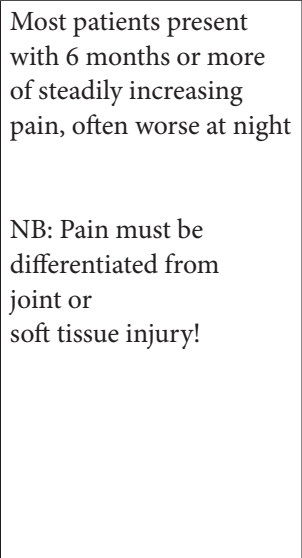 & $\begin{array}{l}\text { No sufficient data } \\
\text { available }\end{array}$ & $\begin{array}{l}\text { Femur }>\text { pelvis }> \\
\text { humerus }>\text { ribs }> \\
\text { tibia }>\text { scapula }> \\
\text { hand }\end{array}$ \\
\hline $\begin{array}{l}\text { Coley BL, } \\
\text { Higinbotham NL } \\
{[19]}\end{array}$ & $\begin{array}{l}52 \text { sCS } \\
\text { [21 sCS in pre- } \\
\text { existing SO and } \\
4 \text { in pre-existing } \\
\text { MO] }\end{array}$ & $\begin{array}{l}23 \text { in pre-existing } \\
\mathrm{SE} \\
4 \text { in pre-existing } \\
\mathrm{ME}\end{array}$ & $\begin{array}{l}27 \text { sCS (pre-existing } \\
\text { enchondroma): } 41 \\
\text { years (mean age) } \\
\\
\text { All cartilage lesions: } \\
31 \text { males and } 21 \text { females }\end{array}$ & Pain (in most of patients) & $\begin{array}{l}18 \text { months - } 30 \\
\text { years (in all of the } \\
\text { patients) } \\
8 \text { cases exceeded } \\
10 \text { years }\end{array}$ & $\begin{array}{l}\text { Femur (19), ilium } \\
\text { (12), tibia (6), } \\
\text { Humerus (4) and } \\
\text { others (scapula, } \\
\text { hand, sternum, } \\
\text { ribs, fibula) }\end{array}$ \\
\hline Liu J et al. [20] & 55 ME (M. Ollier) & $\begin{array}{l}16 \text { with malignant } \\
\text { bone neoplasms } \\
(29,1 \%): 12 \\
\text { CS, } 2 \text { dCS, one } \\
\text { chordoma, and } \\
\text { one osteosarcoma }\end{array}$ & $\begin{array}{l}\text { sCS: Average age } 40.5 \\
\text { years (range } 13-69 \\
\text { years) } \\
\text { Approximately } 33 \% \\
\text { of the patients were in } \\
\text { the fifth decade of life } \\
- \\
6 \text { males, } 10 \text { females } \\
\end{array}$ & $\begin{array}{l}3 \text { patients complained } \\
\text { of pain only, } 8 \text { noted } \\
\text { pain and mass, one has } \\
\text { abnormalities of vision, } \\
\text { and } 4 \text { had pronounced } \\
\text { bony deformities and } \\
\text { pain }\end{array}$ & $\begin{array}{l}\text { No sufficient data } \\
\text { available }\end{array}$ & $\begin{array}{l}\text { Distal femur } \\
\text { (4), shaft of } \\
\text { the femur (1), } \\
\text { proximal femur } \\
\text { (3), proximal } \\
\text { tibia (3), pelvis } \\
\text { (2), proximal } \\
\text { Humerus (1), } \\
\text { proximal ulna (1), } \\
\text { foot (1) }\end{array}$ \\
\hline Mirra JM [21] & $\begin{array}{l}51 \text { central } \\
\text { cartilaginous } \\
\text { tumors } \\
9 \text { primary and } \\
\text { secondary CS1 }\end{array}$ & $\begin{array}{l}11 \text { sCS of } 21 \\
\text { patients (with CS) } \\
\text { with pre-existing } \\
\text { SE and ME }\end{array}$ & $\begin{array}{l}\text { Enchondroma } \rightarrow \text { sCS1: } \\
16-67 \text { years (average } \\
43 \text { years) } \\
\text { Enchondroma } \rightarrow \text { sCS2: } \\
50-64 \text { years (average } \\
58 \text { years) }\end{array}$ & $\begin{array}{l}97 \% \text { of patients with } \\
\text { malignancy presented } \\
\text { with pain, } 24 \% \text { with } \\
\text { conventional and clearcell } \\
\text { CS presented with a mass. } \\
83 \% \text { of those with fibro- } \\
\text { or osteosarcomatous } \\
\text { transformation had } \\
\text { a mass. }\end{array}$ & & - \\
\hline
\end{tabular}


Table 1. (continued)

\begin{tabular}{|c|c|c|c|c|c|c|}
\hline Author & $\begin{array}{l}\text { (Pre-existing) } \\
\text { Lesion } \\
\text { (No.) }\end{array}$ & $\begin{array}{l}\text { Secondary } \\
\text { chondrosarcoma } \\
\text { / Pre-existing } \\
\text { lesion } \\
\text { (No.) }\end{array}$ & $\begin{array}{l}\text { Age at the diagnosis } \\
\text { of secondary } \\
\text { chondrosarcoma } \\
\text { Sex distribution }\end{array}$ & $\begin{array}{l}\text { Cinical presentation - } \\
\text { Symptoms of malignant } \\
\text { transformation }\end{array}$ & $\begin{array}{l}\text { Time of diagnosed } \\
\text { malignancy after } \\
\text { primary diagnosis } \\
\text { - follow up }\end{array}$ & $\begin{array}{l}\text { Localisation of } \\
\text { sCS }\end{array}$ \\
\hline & $\begin{array}{l}12 \text { primary and } \\
\text { secondary CS II } \\
\text { / III }\end{array}$ & & $\begin{array}{l}\text { Patients with SE } \\
\text { transforming to CS } \\
\text { further transforming } \\
\text { to a fibro- or } \\
\text { osteosarcoma were on } \\
\text { the average } 23 \text { years } \\
\text { older than those with } \\
\text { enchondroma ( } 62 \\
\text { versus } 39 \text { years). } \\
\text { Patients with ME } \\
\text { were } 14 \text { years younger } \\
\text { (average, } 36 \text { years) } \\
\text { when they presented } \\
\text { with CS compared } \\
\text { with the rest of the } \\
\text { chondrosarcoma group } \\
\text { (average } 50 \text { years). } \\
\text { - } \\
\text { No data on sex } \\
\text { distribution }\end{array}$ & $\begin{array}{l}\text { No patients with pure, } \\
\text { solitary enchondroma } \\
\text { had a mass; } 44 \% \text { of these } \\
\text { patients did } \\
\text { present with pain. }\end{array}$ & & - \\
\hline $\begin{array}{l}\text { Schaison et al. } \\
\text { [22] }\end{array}$ & $\begin{array}{l}29 \mathrm{sCS} \text { in } 25 \\
\text { patients with } \\
\text { multiple cartilage } \\
\text { disease }\end{array}$ & $\begin{array}{l}12 \mathrm{sCS} \text { (arising } \\
\text { in ME, and } \\
\text { one arising } \\
\text { in Maffucci- } \\
\text { syndrome) } \\
\text { ( } 12 \% \text { secondary } \\
\text { CS of all } \\
\text { cartilaginous } \\
\text { tumors) }\end{array}$ & $\begin{array}{l}\text { sCS: } 19 \text { to } 53 \text { years } \\
\text { (mean age } 36.4 \text { years) }\end{array}$ & $\begin{array}{l}7 \text { cases with increased } \\
\text { tumor volume or } \\
\text { development of a tumor } \\
\text { and pain in } 11 \text { patients }\end{array}$ & $\begin{array}{l}\text { No sufficient data } \\
\text { available }\end{array}$ & $\begin{array}{l}\text { Preference for } \\
\text { the long bones } \\
\text { of the lower limb } \\
(57 \%) \text {, particularly } \\
\text { the distal femur } \\
(32 \%) \text {. } \\
\text { Involvement } \\
\text { of the limb } \\
\text { extremities is } \\
\text { more exceptional } \\
(13.5 \%) \text { in } \\
\text { Ollier disease } \\
\text { and Maffucci } \\
\text { syndrome. }\end{array}$ \\
\hline $\begin{array}{l}\text { Schwartz et al. } \\
{[23]}\end{array}$ & 44 (37 ME, 7 MS) & $\begin{array}{l}4 \text { sCS (arising in } \\
37 \mathrm{ME})(10,81 \%) \\
4 \text { Patients (MS) } \\
\text { with } 5 \text { sCS (one } \\
\text { patient with } 2 \\
\text { sCS) }(57 \%)\end{array}$ & $\begin{array}{l}\text { sCS (pre-existing ME): } \\
16 \text { - } 54 \text { years (median } \\
32 \text { years) }\end{array}$ & $\begin{array}{l}\text { No sufficient data } \\
\text { available }\end{array}$ & $\begin{array}{l}11 \text { - } 53 \text { years } \\
\text { (median } 28 \text { years) }\end{array}$ & $\begin{array}{l}\text { Femur > tibia > } \\
\text { others } \\
\text { N: Four of the } \\
\text { seven patients } \\
\text { who had Maffucci } \\
\text { syndrome had at } \\
\text { least two malignant } \\
\text { tumors each }\end{array}$ \\
\hline Sun et al. [24] & $\begin{array}{l}9 \text { Maffucci } \\
\text { syndrome }\end{array}$ & $\begin{array}{l}5 \mathrm{sCS}(55 \%) \\
\text { (1 patient with } \\
\text { a secondary CS on } \\
\text { the hand) }\end{array}$ & $\begin{array}{l}\text { sCS (pre-existing MS): } \\
13-55 \text { years (median } \\
54) \\
- \\
2 \text { males and 3sfemales }\end{array}$ & Pain in all patients & 6 months -5 years & $\begin{array}{l}\text { Femur, tibia, } \\
\text { fibula, [cuboid, } \\
\text { phalanx] }\end{array}$ \\
\hline
\end{tabular}


Table 1. (continued)

\begin{tabular}{|c|c|c|c|c|c|c|}
\hline Author & $\begin{array}{l}\text { (Pre-existing) } \\
\text { Lesion } \\
\text { (No.) }\end{array}$ & $\begin{array}{l}\text { Secondary } \\
\text { chondrosarcoma } \\
\text { / Pre-existing } \\
\text { lesion } \\
\text { (No.) }\end{array}$ & $\begin{array}{l}\text { Age at the diagnosis } \\
\text { of secondary } \\
\text { chondrosarcoma }\end{array}$ & $\begin{array}{l}\text { Cinical presentation - } \\
\text { Symptoms of malignant } \\
\text { transformation }\end{array}$ & $\begin{array}{l}\text { Time of diagnosed } \\
\text { malignancy after } \\
\text { primary diagnosis } \\
\text { - follow up }\end{array}$ & $\begin{array}{l}\text { Localisation of } \\
\text { sCS }\end{array}$ \\
\hline Unni KK [4] & $\begin{array}{l}78 \text { Chondromatosis } \\
\text { ( } 54 \text { with benign } \\
\text { multiple } \\
\text { chondromas and } \\
24 \text { with secondary } \\
\text { sarcomas) }\end{array}$ & \begin{tabular}{|l}
24 secondary \\
sarcomas (30.8\%) \\
with 10 pre- \\
existing ME, \\
5 pre-existing \\
MS and 6 pre- \\
existing multiple \\
chondromas. Two \\
patients with 2 \\
sCS \\
(19 CS, 3 dCS, \\
1 chondroid \\
sarcoma, 1 \\
osteosarcoma)
\end{tabular} & $\begin{array}{l}\text { (All of the) sCS: } 52 \% \\
\text { in the third and forth } \\
\text { decade of life } \\
\text { Approximately } 57 \% \\
\text { were males }\end{array}$ & $\begin{array}{l}\text { Pain as significant } \\
\text { symptom. } \\
\text { In the pelvic girdle or } \\
\text { spinal column referred } \\
\text { pain may precede local } \\
\text { pain. }\end{array}$ & $\begin{array}{l}\text { Patients with sCS } \\
\text { are somewhat } \\
\text { younger } \\
\text { than patients } \\
\text { with primary } \\
\text { chondrosarcoma }\end{array}$ & $\begin{array}{l}\text { Pelvis }>\text { proximal } \\
\text { femur }>\text { ribs }> \\
\text { humers }>\text { scapula. }\end{array}$ \\
\hline $\begin{array}{l}\text { Unni KK, Dahlin } \\
\text { DC [25] }\end{array}$ & $36 \mathrm{ME}$ & $\begin{array}{l}10 \text { with malignant } \\
\text { bone neoplasms (8 } \\
\mathrm{CS}, 1 \text { chondroid } \\
\text { chordoma, } 1 \mathrm{dCS}) \\
(27,7 \%) \\
\text { In } 419 \text { primary } \\
\text { or sCS of bone } \\
\text { none of the } \\
\text { lesions had arisen } \\
\text { from a clearly } \\
\text { recognizable } \\
\text { pre-existing } \\
\text { enchondroma }\end{array}$ & $\begin{array}{l}\text { No sufficient data } \\
\text { available }\end{array}$ & $\begin{array}{l}\text { No sufficient data } \\
\text { available }\end{array}$ & $\begin{array}{l}\text { No sufficient data } \\
\text { available }\end{array}$ & $\begin{array}{l}\text { Femur (3), tibia } \\
\text { (3), humerus, } \\
\text { [metatarsal (1)], } \\
\text { skull (1) }\end{array}$ \\
\hline $\begin{array}{l}\text { Vazquez-Gracia } \\
\text { et al. [26] }\end{array}$ & 15 Ollier disease & $\begin{array}{l}5 \mathrm{sCS} \text { in } 4 \text { patients } \\
(23.5 \%)\end{array}$ & median 45 years & $\begin{array}{l}\text { Pain and growth in most } \\
\text { cases }\end{array}$ & $\begin{array}{l}\text { No sufficient data } \\
\text { available }\end{array}$ & $\begin{array}{l}\text { Distal femur }> \\
\text { pelvis }>\text { fibula }\end{array}$ \\
\hline $\begin{array}{l}\text { Verdegaal et al. } \\
{[15]}\end{array}$ & $\begin{array}{l}144 \text { Ollier disease } \\
17 \text { Maffucci } \\
\text { syndrome } \\
\text { Ollier disease: } \\
\text { mean age was } 13 \\
\text { years (range, } 0-59 \\
\text { years; data from } \\
105 \text { of } 141 \text { patients } \\
\text { with Ollier } \\
\text { disease). } \\
\text { Maffucci syndrome: } \\
\text { mean age was } 12 \\
\text { years (range } 1-65 \\
\text { years; data } \\
\text { completed for } 11 \text { of } \\
17 \text { patients }\end{array}$ & $\begin{array}{l}66 \text { patients (41\%) } \\
\text { developed one or } \\
\text { more sCS } \\
\text { Ollier disease } \\
\mathrm{n}=57(45,8 \%) \\
\\
\text { Maffucci } \\
\text { syndrome } \mathrm{n}=9 \\
(52,9 \%) \\
\\
\text { Of } 66 \text { patients, } \\
48 \text { developed } \\
\text { one CS, } 18 \\
\text { developed two to } \\
\text { four CS. Of these } \\
18 \text { patients, 33\% } \\
\text { had synchronous } \\
\text { and } 56 \% \text { had } \\
\text { metachronous CS } \\
\text { (unknown n=2). }\end{array}$ & $\begin{array}{l}\text { Mean age at } \\
\text { first surgery for } \\
\text { chondrosarcoma: } \\
\text { sCS (pre-existing ME): } \\
33 \text { (range 10-59 years) } \\
\text { sCS (pre-existing MS): } \\
30 \text { (range } 14-51 \text { years) }\end{array}$ & $\begin{array}{l}\text { No sufficient data } \\
\text { available }\end{array}$ & $\begin{array}{l}\text { No sufficient data } \\
\text { available }\end{array}$ & $\begin{array}{l}\text { Femur (18), tibia } \\
\text { (10), Humerus } \\
\text { (10), flat bones ( } 8 \\
\text { scapula, } 11 \text { pelvis) } \\
\\
\text { [Of the small } \\
\text { tubular bones, the } \\
\text { metacarpals } \\
\text { and metatarsals } \\
\text { were less often } \\
\text { involved than the } \\
\text { phalanges of the } \\
\text { hands and feet } \\
\text { ( } \mathrm{n}=9 \text { and } \mathrm{n}=14, \\
\text { respectively)] }\end{array}$ \\
\hline
\end{tabular}

$\mathrm{E}=$ Enchondroma, $\mathrm{SE}=$ Solitary Enchondroma, $\mathrm{ME}=$ Multiple Enchondromas $/$ Enchondromatosis, $\mathrm{MO}=$ multiple Osteochondroma, $\mathrm{MS}=\mathrm{Maffucci}$ Syndrom, $\mathrm{CS}=$ Chondrosarcoma, $\mathrm{sSC}=$ secondary Chondrosarcoma, $\mathrm{dCS}=$ dedifferentiated Chondrosarcoma 
Another study group could not confirm this finding of an activating mutation in the parathyroid hormone receptor type 1 (PTHR1) gene. Rozeman et al. investigated PTHR1 in enchondromas and chondrosarcomas from 31 enchondromatosis patients from three different European countries, thereby excluding a population bias [36]. PTHR1 protein expression was studied using immunohistochemistry, revealing normal expression. The presence of the described PTHR1 mutation was analyzed, in tumors from 26 patients [36]. In addition, 11 patients were screened for other mutations in the PTHR1 gene by sequence analysis. They could neither confirm the previously found mutation nor find any other mutations in the PTHR1 gene. Thus, PTH1R mutations may contribute to the disease in a small subset of Ollier patients but is probably not causative for the disease [36].

Recently, mutations in the gene encoding isocitrate dehydrogenase 1 (IDH1) and IDH2 were detected in solitary cartilaginous tumors as well is in patients with multiple enchondromas $[15,37]$. These mutations might represent early postzygotic genetic events and account for the initiation of the disease process $[15,37]$. Furthermore, rearrangements of chromosome 6 and the long arm of chromosome 12 (particularly q13q15) seem to be recurrent in chondromas, also including soft tissue chondromas [38]. Array comparative genomic hybridization data showed highly variable genetic abnormalities including gain and loss of several chromosomes [39].
For further chondrosarcoma development, a multistep genetic model is presumed. Complex karyotypes are found especially in high-grade chondrosarcoma, and $96 \%$ of them contains alterations at some level in the pRb pathway [40, $41]$.

Imaging. Conventional radiographs in two planes should always be the first imaging method used. MRI and CT should be used when diagnosis is difficult because they offer ability to visualize more clearly calcification, periosteal bone formation, cortical destruction or soft tissue involvement [23, 42-47].

Standard $\mathrm{x}$-rays were suspicious for an aggressive tumor when extended endosteal scalloping, cortical remodelling (expansion of normal bone contour), cortical destruction, pathologic fracture and/or periosteal reaction were evident $[1$, $21,29,42]$. On computed tomography, characteristic features of malignancy were lytic areas, especially when pronounced in comparison with previously made radiographs, cortical lesions with a scalloping greater than $2 / 3$ of the cortex or extension to soft tissue [29, 42-48].

Magnetic resonance (MR) of an enchondroma demonstrates a lobulated lesion with intermediate signal intensity on T1-weighted images and predominantly high signal intensity on $\mathrm{T} 2$-weighted sequences.

The malignant progression of an enchondroma was in most cases evident if one of the following criteria was present (in MRI): cortical destruction, moth-eaten or permeative osteolysis, spontaneous pathologic fracture, periosteal reac-

Table 2. Clinical and radiographic (risk) factors of secondary chondrosarcoma in enchondroma(tosis)

\begin{tabular}{|c|c|}
\hline $\begin{array}{l}\text { Clinical }[14,15,18,20-24,27,28, \\
43,48]\end{array}$ & $\begin{array}{l}\text { - Pain } \\
\text { - Increasing tumor size } \\
\text { - Palpable mass } \\
\text { - Localisation: femur, proximal humerus, scapula, (tibia) } \\
\text { - Localisation: pelvis (primary chondrosarcoma?) } \\
\text { - Age in the mid 30s }\end{array}$ \\
\hline Radiographic $[29,42-47,49-59]$ & $\begin{array}{l}\text { - Cortical destruction } \\
\text { - Moth-eaten or permeative osteolysis } \\
\text { - Spontaneous pathologic fracture } \\
\text { - Periosteal reaction } \\
\text { - Oedema surrounding the tumor } \\
\text { - } \text { predominantly intermediate signal on T1-weighted images (in discussion) } \\
\text { - } \text { multilocular appearance on contrast-enhanced T1-weighted images (in discussion) } \\
\text { - Soft tissue mass } \\
\text { - Endosteal scalloping }>2 / 3 \text { of the cortex (with limitation in the metaphyseal region where the cortex is thin, } \\
\text { - especially in the proximal fibula) } \\
\text { - Extent of endosteal scalloping superior to two-thirds of the lesion length } \\
\text { - Increased uptake in scintigraphy (more than that of the anterior iliac crest) } \\
\text { - Lesion size }>5-6 \mathrm{~cm} \text { (risk factor) }\end{array}$ \\
\hline $\begin{array}{l}\text { Pre-existing Lesion - } \\
\text { Risk of malignant transformation } \\
{[10,15,24]}\end{array}$ & $\begin{array}{l}\text { Enchondroma: risk of malignant transformation up to } 4 \% \text {, on average about } 2 \% \\
\text { - } \text { Enchondromatosis / Ollier disease: risk of malignant transformation up to } 46 \% \\
\text { - } \text { Maffucci syndrome: risk of malignant transformation up to } 55 \%\end{array}$ \\
\hline Genetics $[8,15,34-37,40,41]$ & $\begin{array}{l}\text { - } \text { Mutation in parathyroid hormone receptor } 1 \text { (PTHR1)? } \\
\text { - } \text { Rearrangements of chromosome } 6 \text { and chromosome } 12 \\
\text { - PTPN11 mutations } \\
\text { - } \text { Alterations at some level in the pRb pathway } \\
\text { - } \text { Other highly variable genetic alterations }\end{array}$ \\
\hline
\end{tabular}




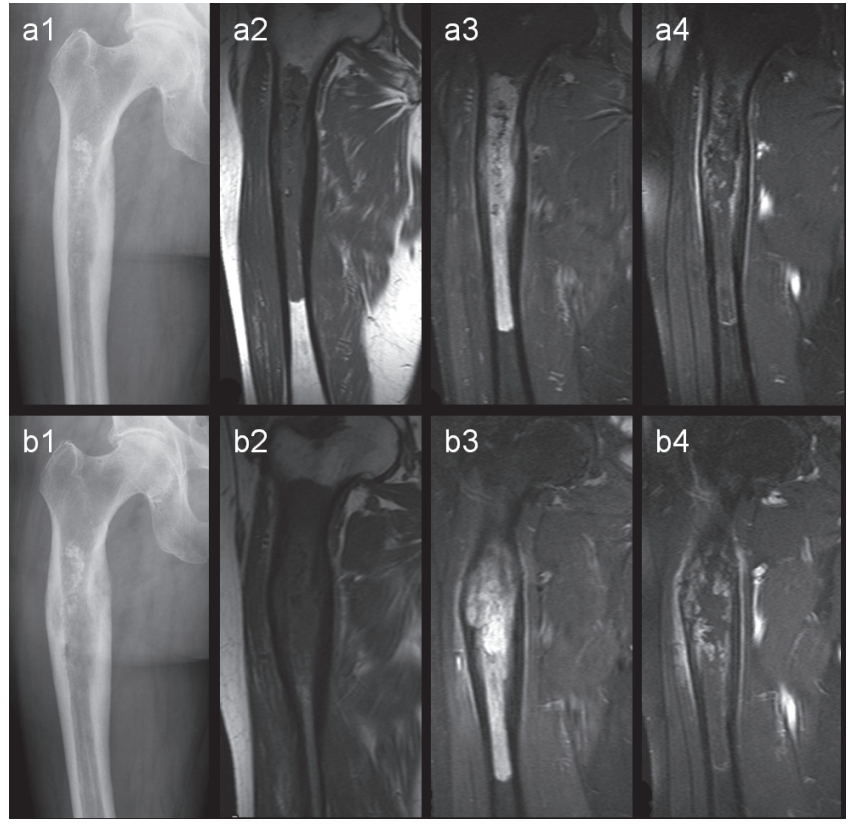

Figure 4 (a1-a4 and b1-b4): Secondary chondrosarcoma in 77-year-old woman with right leg pain. a: Initial plain film radiography (a1) shows evidence of enchondroma (DD chondrosarcoma) with calcifications of the chondroid matrix in the proximal femoral diaphysis. MRI demonstrates an enchondroma with characteristic SI on T1-weighted and on STIR images (a2, a3). Contrast-enhanced T1-weighted image (a4) shows a "ring-andarc" pattern of contrast enhancement. There is no perilesional soft- tissue mass. An incisional biopsy of the tumor confirmed the diagnosis of an enchondroma. b: Six months after the initial examination, the lesion showed expansion of the proximal femoral bone and a soft tissue extension, suggesting sarcomatous transformation. Another incisional biopsy was performed and the histological specimens showed an intermediate grade (grade II) chondrosarcoma.

tion, edema surrounding the tumor on MR images, and soft tissue mass $[2,29,42-47,49]$. Note that the use of scalloping in the diagnosis is limited when examining the metaphyseal region because the cortex is thin, especially in the proximal fibula [29].

In a recent study the predominantly intermediate signal on T1-weighted images [72\% (13/18) in low-grade chondrosarcoma vs. $25 \%(4 / 16)$ in enchondroma], multilocular appearance on contrast-enhanced T1-weighted images [83\% $(15 / 18)$ vs. $44 \%(7 / 16)]$ was also discussed for differentiating low-grade chondrosarcoma from enchondroma [50].

The radiological aspects that were suspicious for a secondary chondrosarcoma are summarized in Table 2 (Figure 4 and 5).

In addition, lesion sizes of enchondroma and chondrosarcoma were often different. Malignant lesions had the expected larger average size. Although there is certainly overlap in size range, lesions larger than 5-6 $\mathrm{cm}$ in diameter are much more likely to represent chondrosarcoma [42].

If malignancy is diagnosed, general staging should be carried out to assess the extent to which the disease has spread

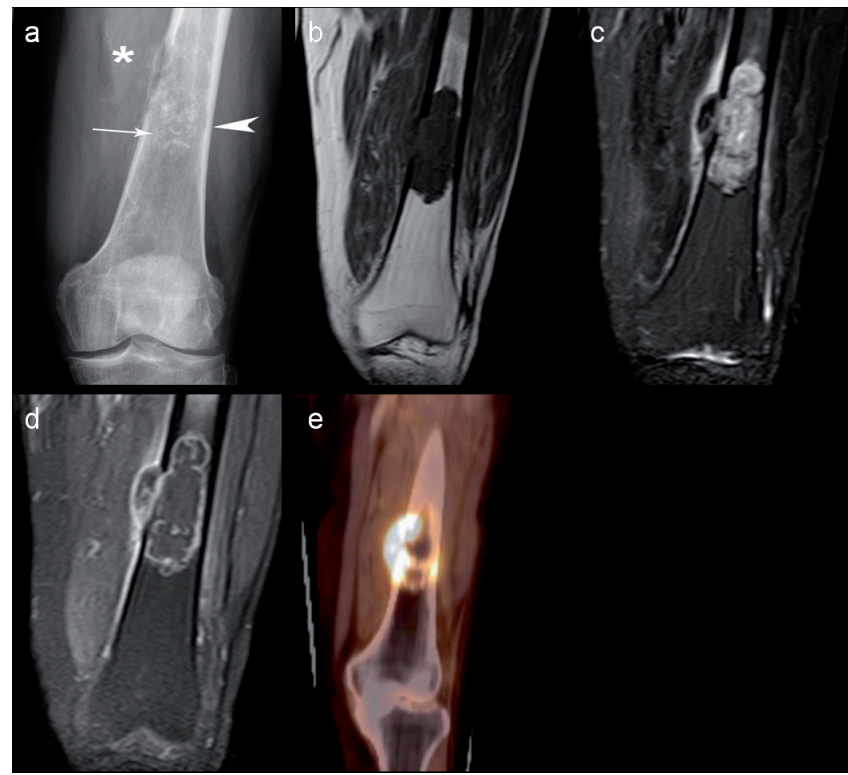

Figure 5. (a-e): 76-year-old man with persistent left leg pain. a: Radiograph demonstrates a dedifferentiated chondrosarcoma with bimorphic features in the left femoral diaphysis. There are calcifications within a part of the lesion (arrow), which is characteristic of a chondroid tumor. An area with endosteal scalloping (arrowhead), cortical thickening and calcifications is adjacent to a more aggressive-appearing area with cortical disruption and periosteal reaction $\left.{ }^{*}\right)$. These findings indicate malignancy and the possibility of a biphasic tumor type. Coronal T1-weighted (B, TR/TE, 500/18), STIR (C, TR/TE, 2,800/60) and gadolinium-enhanced T1-weighted (D, TR/TE, 500/18) MR images demonstrate a periosteal reaction and a cortical breakthrough. Extension into the soft-tissue and a perilesional soft-tissue edema with contrast-enhancement is seen on MRI images. e: FDG PETCT shows a circumscribed focus of intense uptake (Note: Histological examination showed a dedifferentiated chondrosarcoma consisting of two different components, an underlying benign enchondroma juxtaposed to a high-grade osteosarcoma)

including bone scintigraphy and chest radiographs and CT [42-48]; small nodules are not specific for malignancy Whole body MRI and PET are under evaluation for both staging and treatment response evaluation.

\section{Nuclear medicine.}

Bone scintigraphy. In the actual ESMO-guideline for diagnosis, treatment and follow-up of bone sarcomas, bone scintigraphy is recommended for initial staging of chondrosarcomas, as further skeletal lesions can be excluded by this examination [52]. It has been reported that radionuclide uptake is generally higher in chondrosarcoma than in enchondroma [42]. Compared to the tracer uptake in the anterior iliac crest, the uptake was, in difference to the majority of examined enchondromas, higher in $82 \%$ of the examined chondrosarcomas. A correlation between intensity or pattern of uptake and histological grades was not found [53]. In chondrosarcoma it could be variable, but often in- 


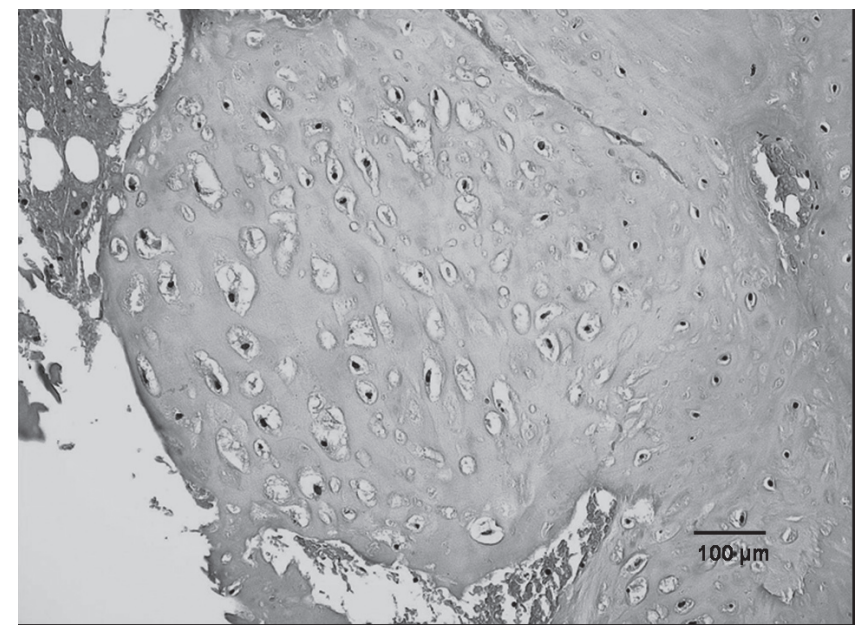

Figure 6. Enchondroma located in the humerus (female, 33y). Chondrocytes located within sharp-edged lacunar spaces (H\&E, x100).

tense [53-55]. Sometimes uptake in the centre of the lesion is lower than around its periphery ("doughnut" sign). However, a typical tumor pattern of distribution demonstrates areas of focal increased uptake throughout the tumor [53].

FDG-PET: In several publications increased uptake of the radiotracer was reported in chondrosarcomas, showing a positive correlation of the uptake intensity (measured as SUV) and tumor grade [56-61]. Significant differences between SUVmax levels in benign lesions/grade I chondrosarcomas and high-grade chondrosarcomas were found; such differences were not found between the SUVmax in benign cartilage tumors and grade I chondrosarcomas. With the use of 2.3 as the cut-off level for SUVmax, the positive predictive value of FDG-PET in this study was 0.82 in the diagnosis of grade II and grade III chondrosarcomas; the negative predictive value was 0.96 [58].

Based on these data, FDG-PET is a valuable tool to distinguish benign lesions and low grade (grade I) chondrosarcoma from intermediate (grade II) and high grade (grade III) chondrosarcoma. This can be of special interest for the prediction of a focus of dedifferentiation in patients with Ollier disease or Maffucci syndrome [61].

Beside the application of FDG-PET in the primary diagnosis and further characterisation of chondrosarcoma, it can be a useful tool for the diagnosis of metastatic disease and tumor recurrence in follow-up [59], especially in cases of limitations of CT and MRI due to metallic prosthesis. For biopsy planning, FDG-PET may be useful to localise the tumor site with the highest metabolic activity for selective sampling in cases of heterogeneous cartilage lesions [56]. This is of special interest as chondrosarcomas may have significantly different grades in different portions of the lesion.

Pathology. The diagnosis of secondary chondrosarcoma is confirmed by histological examination of biopsy samples. Like

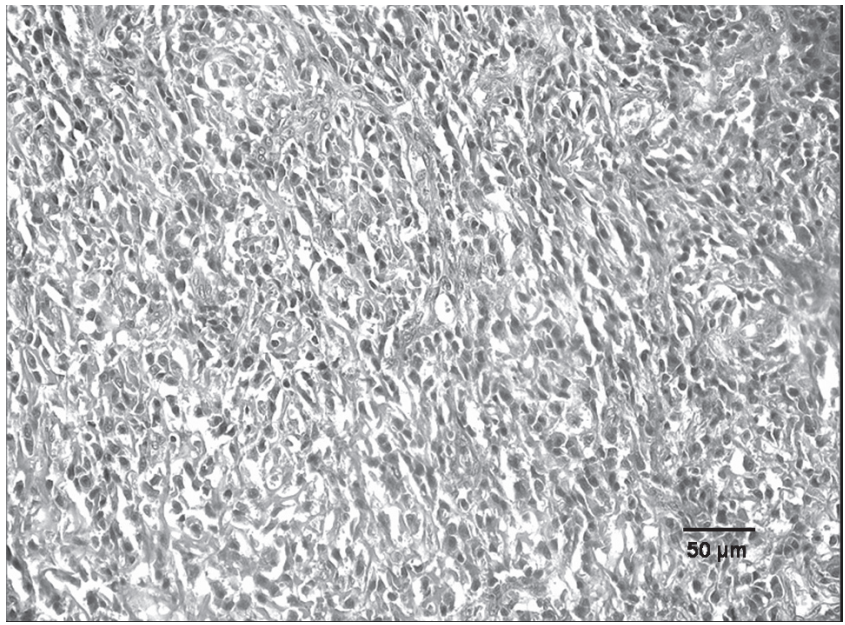

Figure 7. High-grade chondrosarcoma (male, 77y) arising in an enchondroma of the femur showing high cellularity of highly atypical tumor cells (H\&E, $\mathrm{x} 200)$

conventional chondrosarcoma, secondary chondrosarcoma is not always easy to diagnose, and the histological features alone may not be sufficient to determine that a lesion has become malignant $[3,18]$. However, a clearly benign enchondroma shows the typical pathological features (Figure 6).

Most secondary chondrosarcomas are low grade. The overlap in appearance between benign lesions and low-grade cartilage tumors has led to a high rate of inter- and intraobserver variability in diagnosis [62]. Therefore, information from the clinical history and imaging studies must be correlated with the pathologic data to render the correct diagnosis [3, 63].

On the pathology slides, sarcomatous transformation is usually identified by the presence of malignant chondroid tissue: Hypercellularity, binucleated cells, multiple cells in lacunae, atypical nuclei, and myxoid changes in the hyaline cartilage matrix (Figure 7) $[3,14]$. An important feature consistent with malignancy is permeative infiltration of soft tissues and the presence of discrete nodules of cartilage in the soft tissues separated from the main tumor mass $[18,64]$. Additional indicators of malignancy are the "chondrosarcoma permeation pattern" and infiltration of Haversian systems [14].

The grading of secondary chondrosarcomas is similar to that of primary chondrosarcomas and includes grade 1, low; grade 2, intermediate; and grade 3, high [65]. Most secondary chondrosarcomas are grade 1 or 2 lesions [48]. Only $1 \%$ of cases were reported to be grade 3 [18].

\section{Biopsy}

Usually it is advised to determine the local staging of the lesion before the biopsy. This biopsy of a suspected primary malignant bone tumor should be carried out at a medical centre, ideally by the surgeon who is to carry out the definitive tumor resection [66]. It should be planned so the entire 
skin incision and biopsy track can be incorporated into the definitive surgical field [67]. In addition, the biopsy should provide sufficient tissue for gross pathological evaluation, histological analysis, immunohistochemistry and, if needed, cytogenetic testing.

\section{Surgery}

When histology confirms the diagnosis of a chondrosarcoma, there are basically two categories for surgical treatment of a secondary chondrosarcoma [68]. The first is (intralesional) curettage, adjunct chemical or thermal ablation, and cementation or bone grafting of the defect. The second is wide excision with structural graft or reconstruction [68].

Acceptable oncologic and functional results have been observed in patients with grade 1 chondrosarcoma treated with curettage and cryosurgery alone [64, 69]. However, local recurrence is not unusual if there is inadequate resection [68, 69]. Wide excision is performed in higher grade chondrosarcomas, and occasionally in grade 1 chondrosarcoma. Large lesions and chondrosarcomas in anatomic locations that do not allow adequate margins or complete excision (e.g. spine, craniofacial region, ribs and pelvis) have an obvious increased risk of local recurrence and metastatic disease [70,71].

Additionally, there it is still a point of contention around the removal of a large enchondroma before the age of 32 since many chondrosarcomas can demonstrate a precursor enchondroma, and if the average age of a patient with primary or secondary CS was about 52 years, the initial "seeds" of malignancy probably developed around age 32 [14].

\section{Follow up}

The knowledge on the potential risk of undergoing malignancy requires a standardised follow up, since the risk of malignant transformation ranged up to $45.8 \%$ in patients with Ollier disease and $57 \%$ in patients with Maffucci syndrome, respectively (Table 1). And, increased risk of transformation of a solitary enchondroma in long and flat bones (scapula and pelvis) makes it necessary to follow up these patients too. But one should be aware of the fact that (solitary) enchondroma in the pelvis is very rare or may does not exist and lesion represents primarily a chondrosarcoma. Because of the different biology and clinical course of the tumors of the phalanx, these are not discussed in our paper.

In general, most of the studies propose clinical as well as radiological controls. The frequency of skeletal surveys must be weighed against the risk of cumulative radiation exposure. In a paper of Lin et al., the recommended follow up was to conduct surveys every one to two years with focal radiographs of symptomatic areas [18]. In a recent study the following was recommended in cases where two or more enchondromas are detected: staging should include a technetium scan and $\mathrm{X}$-rays of each enchondroma to establish a baseline for future comparison [15]. Additionally, screening of enchondroma of the long and/or flat bones should be done more carefully using plain $\mathrm{x}$-rays when complaints of pain, swelling, or neurological disorders appear or increase [15].

This may be in contrast to the fact, that there are lesions undergoing malignant transformation without clinical symptoms. As mentioned, up to $19 \%$ of patients may not suffer from pain $[27,30]$. And it should be noted that in most cases it is not possible to sufficiently interpret X-rays of anatomically difficult regions (pelvis, e.g.). Furthermore, signs of malignant transformation such as permeative osteolysis (in bone marrow), periosteal reaction (except periosteal/cortical bone remodelling) and oedema surrounding the tumor could be sufficiently detected only by MRI.

Recently, extended recommendations for the management of a solitary central cartilaginous tumor of long bones were published, depending on their clinical and radiographic appearance [29]. This classification is very practical, however, this proposed classification of cartilage tumors into aggressive, active, potentially active and quiescent lesions has not been shown to differentiate between enchondroma and chondrosarcoma in detail and has not been clinically validated yet.

Following the results of this review and summarising data from the literature, we would like to recommend our opinion on the initial diagnostic and follow up of patients:

Initial diagnostic. Choice of radiological modality depends on the lesions location. Plain radiographs are the standard. In anatomically difficult regions (pelvis and scapula, e.g.) CT scan could be considered. In addition, MRI is recommended as the method of choice to reduce inter-observer variability on evaluation of X-rays and because MRI affords the possibility of assessing the medullary spread of tumor (tumor size), visualisation of any reaction of the periost, assessment of the surrounding oedema and evaluation of the T1- and T2 signal intensity.

If two or more than two lesions are known, additionally a bone scintigraphy is recommended for screening for an underlying enchondromatosis. However, one should recognize the possibility of a whole body MRI, since this method has no radiation exposure and there is the possibility to describe the real size and characteristics of the lesion, if detected.

Enchondromas which at initial diagnosis raise clinical or radiological suspicion of a low-grade chondrosarcoma (Table 2) should be discussed in a multidisciplinary team in orthopaedic oncology centre and may require biopsy. The histology results inform subsequent steps.

Follow up of solitary enchondroma. In view of the fact that the vast majority of patients with chondrosarcoma suffer from pain, a pragmatic approach would be to rely on the occurrence of pain in the case of solitary enchondromas which are innocuous on imaging at the time of diagnosis [27-30].

In contrast, when tumor is located in the pelvis, proximal femur, humerus or scapula, and/or size $>5-6 \mathrm{~cm}$ an annual clinical examination and an annual/biennial (depending of risk factors) MRI of the affected area should be performed, 
Table 3. Recommendation for initial management and follow up of enchondroma(tosis) of the axial skeleton and the long bones in asymptomatic patient

\begin{tabular}{|c|c|c|}
\hline Enchondroma(tosis) & First step(s) / initial management & Recommendation for treatment / follow up \\
\hline $\begin{array}{l}\text { Clinical / radiological suspected malignancy } \\
\text { (criteria seen on Table 2) }\end{array}$ & $\begin{array}{l}\text { Completion of the diagnostic including } \\
\text { plain radiographs, CT, MRI, biopsy. } \\
\text { Scintigraphy on demand }\end{array}$ & Depending on the result of histology \\
\hline $\begin{array}{l}\text { Clinical / radiological unambiguously "enchondroma" with } \\
\text { localisation in pelvis*, femur, scapula, humerus and/or size } \\
>5-6 \mathrm{~cm}\end{array}$ & Follow up & $\begin{array}{l}\text { Annual clinical and annual/biennial radiological } \\
\text { (MRI) examination }\end{array}$ \\
\hline $\begin{array}{l}\text { Clinical / radiological "enchondroma" with localisation in } \\
\text { other sites than pelvis, femur, scapula or humerus and/or } \\
\text { size }<5-6 \mathrm{~cm}\end{array}$ & Follow up & $\begin{array}{l}\text { Annual clinical. Consideration of bi-/triennial } \\
\text { radiological examination (plain radiographs, in } \\
\text { any doubt MRI) }\end{array}$ \\
\hline
\end{tabular}

concerning the higher risk of malignant transformation in these regions and the risk of undergoing "painless" transformation into chondrosarcoma (Table 3). Modest to large solitary enchondromas of long and flat bones probably require at least two decades of follow up if detected and treated after age 25 years [14], maybe they profit from a lifelong follow up.

Follow up of enchondromatosis. When tumor is located in the pelvis, femur, humerus or scapula, and/or size $>5-6 \mathrm{~cm}$ a yearly clinical examination and a MRI of the affected areas (may be in form of a whole body MRI) should be performed. For other locations a clinical survey should be conducted annually and radiographic control should be discussed every two to three years. In addition, if after reviewing X-rays malignancy is suspected or if a clinical symptom (pain) is evident, an MRI should be carried out (Table 3). Patients with enchondromatosis may also profit from a lifetime follow up.

Independently of previous described recommendations: In any case of pain, immediate clarification including clinical and radiological examination (plain radiographs, MRI and if needed CT) is advised.

Follow up of secondary chondrosarcoma. In the event of a secondary chondrosarcoma, follow-up of high-grade tumors should include both a physical examination of the tumor site and assessment of the function and possible complications of any reconstruction. Local imaging and chest X-ray/CT should be the norm. Recommended intervals for follow up after completion of chemotherapy are every six weeks to three months for the first two years; every 2-4 months for years 3-4; every 6 months for years 5-10 and thereafter every 6-12 months according to local practice [52].

\section{Prognosis}

The prognosis of patients with secondary chondrosarcoma is relatively good, and the tumors metastasize infrequently. The overall survival rate at five years is approximately $90 \%[10,71]$. However, several other studies report mortality rates of $11 \%$ to $16 \%$ with $>5$-year follow-up [16]. Metastasis may be more apt to occur in the rare high-grade secondary chondrosarcoma $[10,18,52,70-71]$.

\section{Limitation of this study}

The fact that the presented data were collected from a review of the literature in which data were presented mainly from referral centres for musculoskeletal oncology may have led to a selection bias and the true incidence of malignancy may be lower. Furthermore, the true incidence of malignant transformation is not known as most enchondromas are asymptomatic and go undetected. And the starting point of these cumulative incidence curve estimates was mostly the date of birth of the patient, and the patients follow up wasn't in most cases the date of death. Because of this construction, the probability estimates should not be interpreted as "life-long probabilities" since birth and all probabilities (or proportions) have only a descriptive meaning conditional on the disease having been diagnosed. The proposal for the follow up excluded the tumours of the hand and foot.

\section{Conclusion}

In enchondroma, much more in the enchondromatosis and Maffucci syndrome, the potential of a malignant progression into a secondary chondrosarcoma is a well known fact. And despite the fact that most of the cartilage tumors present with characteristic features on imaging, the differential diagnosis between a tumor being enchondroma and low grade chondrosarcoma remains difficult.

Chondrosarcoma patients (primary CS) have an average age of about 52 years. Patients with a secondary chondrosarcoma (SCS) arising from a solitary enchondroma are about 10 years older. Patients who develop a secondary chondrosarcoma having an enchondromatosis are on average $10-15$ years younger. Main localisations include the pelvis, the scapula, the femur and the humerus. But one should be also aware of the chondrosarcoma of the rib and the tibia.

Clinically, the presence of non-mechanical pain or night pain in any age group is cause for concern and further immediate investigation is warranted. Indeed, pain is the typical symptom when a primarily benign lesion becomes malignant. In contrast benign enchondroma can also cause pain. There- 
fore, pain does not eliminate the benign enchondroma from consideration. And, the absence of pain does not exclude a chondrosarcoma, which also makes a consistent radiological follow up necessary. Several imaging characteristics exist that suggest a secondary chondrosarcoma.

These radiographic risk factors, tumor characteristics, as well as clinical signs are summarised in Table 2. The recommendations for the follow up depend on these findings (Table 3). Especially patients with an enchondromatosis would benefit from lifelong follow up, additionally patients with solitary enchondroma of long bones and flat bones.

Early recognition of a secondary chondrosarcoma following consequently performed clinical and radiological examination and appropriate surgical treatment are necessary for successful outcomes. However, our recommendations must be measured against the long-term gold standard of patient outcomes.

Acknowledgements: We thank Richard McClellan (California, USA) for editing and revision of the manuscript.

\section{References}

[1] DOUIS H, SAIFUDDIN A. The imaging of cartilaginous bone tumors. I. Benign lesions. Skeletal Radiol 2012; 41: 1195-1212. http://dx.doi.org/10.1007/s00256-012-1427-0

[2] LUCAS DR, BRIDGE JA. Chondromas: enchondroma, periosteal chondroma, and enchondromatosis. World Health Organization classification of tumors. In: Fletcher CDM, Unni KK, Mertens F, eds. Pathology and genetics of tumors of soft tissue and bone. Lyon: IARC Press, 2002: 237-240.

[3] ADLER CP. Enchondroma. In: Adler CP. Bone diseases: macroscopic, histological, and radiological diagnosis of structural changes in the skeleton system. 3rd edn. Berlin Heidelberg New York: Springer, 2004: 228-233.

[4] UNNI KK. Chondroma. In: Unni KK, editor. Dahlins bone tumors: general aspects and data on 10165 cases. Philadelphia: Wolters Kluwert/Lippincott William \& Wilkins Health, 2009: 22-40.

[5] PANSURIYA TC, KROON HM, BOVÉE JV. Enchondromatosis: insights on the different subtypes. Int J Clin Exp Pathol 2010; 3: 557-569.

[6] SILVE C, JUPPNER H. Ollier disease. Orphanet J Rare 2006; 1: 37. http://dx.doi.org/10.1186/1750-1172-1-37

[7] SUPERTI-FURGA A, SPRANGER J, NISHIMURA G. Enchondromatosis revisited: new classification with molecular basis. Am J Med Genet C Semin Med Genet 2012; 15; 160C: 154-164. http://dx.doi.org/10.1002/ajmg.c.31331

[8] CERNY M, RUDIGER HA, AUBRY-ROZIER B, DUGERT E, BECCE F. Enchondromatosis (Ollier's Disease). Arthritis Rheum Aug 2013; 5. doi: 10.1002/art.38115 http://dx.doi. org/10.1002/art.38115

[9] SHAPIRO F. Ollier's Disease. An assessment of angular deformity, shortening, and pathological fracture in twenty-one patients. J Bone Joint Surg [Am] 2012; 64: 95-103.
[10] ALTAY M, BAYRAKCI K, YILDIZ Y, EREKUL S, SAGLIK Y. Secondary chondrosarcoma in cartilage bone tumors: report of 32 patients. J Orthop Sci 2007; 12: 415-423. http://dx.doi. org/10.1007/s00776-007-1152-Z

[11] VAN LP, LAMMENS J. Malformation of the Humerus in a patient with Ollier disease treated with the Ilizarov technique. J Shoulder Elbow Surg 2008; 17: e9-11 http://dx.doi. org/10.1016/j.jse.2007.04.006

[12] PANDEY R, WHITE SH, KENWRIGHT J. Callus distraction in Ollier's disease. Acta Orthop Scand 1995; 66: 479-480. http://dx.doi.org/10.3109/17453679508995592

[13] MARTSON A, HAVIKO T, KIRJANEN K. Extensive limb lengthening in Ollier's disease: 25-year follow up. Medicina (Kaunas) 2005; 41: 861-866.

[14] BRIEN EW, MIRRA JM, KERR R. Benign and malignant cartilage tumors of bone and joint: their anatomic and theoretical basis with an emphasis on radiology, pathology and clinical biology. I. The intramedullary cartilage tumors. Skeletal Radiol 1997; 26: 325-353. http://dx.doi.org/10.1007/s002560050246

[15] VERDEGAAL SH, BOVÉE JV, PANSURIYA TC, GRIMER RJ, OZGER H et al. Incidence, Predictive Factors, and Prognosis of Chondrosarcoma in Patients with Ollier Disease and Maffucci Syndrome: An International Multicenter Study of 161 Patients. Oncologist 2011; 16: 1771-1779. http://dx.doi. org/10.1634/theoncologist.2011-0200

[16] GEIRNAERDT MJ, HERMANS J, BLOEM JL, KROON HM, POPE TL et al. Usefulness of radiography in differentiating enchondroma from central grade 1 chondrosarcoma. AJR Am J Roentgenol 1997; 169: 1097-1104. http://dx.doi.org/10.2214/ ajr.169.4.9308471

[17] MOSER RP, KRANSDORF MJ, GILKEY FW, AOKI J. Enchondroma. In Moser RP, editor. Cartilaginous tumors of the skeleton. St. Louis: Mosby - Year Book, 1990: 8-34.

[18] LIN PP, MOUSSALLEM CD, DEAVERS MT. Secondary chondrosarcoma. J Am Acad Orthop Surg 2010; 18: 608-615.

[19] COLEY BL, HIGINBOTHAM NL. Secondary chondrosarcoma. Ann Surg 1954; 139: 547-559. http://dx.doi. org/10.1097/00000658-195405000-00003

[20] LIU J, HUDKINS PG, SWWEE RG, UNNI KK. Bones sarcomas associated with Ollier's disease. Cancer 1987; 59: 1376-1385. http://dx.doi.org/10.1002/1097-0142(19870401)59:7<1376:: AID-CNCR2820590725>3.0.CO;2-F

[21] MIRRA JM, GOLD R, DOWNS J, ECKARDT JJ. A new histologic approach to the differentiation of enchondroma and chondrosarcoma of the bones: A clinicopathologic analysis of 51 cases. Clin Orthop 1985; 201: 214-237.

[22] SCHAISON F, ANRACT P, COSTE F, DE PINIEUX G, FOREST M et al. Chondrosarcoma secondary to multiple cartilage diseases. Study of 29 clinical cases and review of the literature [Article in French]. Rev Chir Orthop Reparatrice Appar Mot 1999; 85: 834-845.

[23] SCHWARTZ HS, ZIMMERMAN NB, SIMON MA, WROBLE RR, MILLAR EA et al. The malignant potential of enchondromatosis. J Bone Joint Surg [Am] 1987; 69: 269-274.

[24] SUN T, SWEE RG, SHIVES TC, UNNI KK. Chondrosarcoma in Maffucci syndrome. J Bone Joint Surg [Am] 1985; 67: 1214-1218. 
[25] UNNI KK, DAHLIN DC. Premalignant tumors and conditions of bone. Am J Surg Pathol 1979; 3: 47-60. http://dx.doi. org/10.1097/00000478-197902000-00006

[26] VAZQUEZ-GARCIA B, VALVERDE M, SAN-JULIAN M. [Ollier disease: benign tumors with risk of malignant transformation. A review of 17 cases]. An Pediatr (Barc) 2011; 74: 168-173. http://dx.doi.org/10.1016/j.anpedi.2010.10.012

[27] MARCO RA, GITELIS S, BREBACH GT, HEALEY JH Cartilage tumors: evaluation and treatment. J Am Acad Orthop Surg 2000; 8: 292-304

[28] PRITCHARD DJ, LUNKE RJ, TAYLOR WF, DAHLIN DC, MEDLEY BE. Chondrosarcoma: A clinicopathologic and statistical analysis. Cancer 1980; 45: 149-157. http:// dx.doi.org/10.1002/1097-0142(19800101)45:1<149::AIDCNCR2820450125>3.0.CO;2-A

[29] PARLIER-CUAU C, BOUSSON V, OGILVIE CM, LACKMAN RD, LAREDO JD. When should we biopsy a solitary central cartilaginous tumor of long bones? Literature review and management proposal. Eur J Radiol 2011; 77: 6-12. http://dx.doi. org/10.1016/j.ejrad.2010.06.051

[30] MARCO R, LANE J, HUVOS A. Intralesional excision of intramedullary low grade chondrosarcoma of the extremity. In 67th annual meeting of the American Academy of Orthopaedic Surgeons. Orlando, Fla: American Academy of Orthopaedic Surgeons (2000)

[31] BANNA M, PARWANI GS (1969) Multiple sarcomas in Maffuci's syndrome. Br J Radiol 1969; 42: 304-307. http://dx.doi. org/10.1259/0007-1285-42-496-304

[32] MAHAFZA WS. Multiple enchondromatosis Ollier's disease with two primary brain tumors. Saudi Med J 2004; 25: 1261-1263.

[33] MERTENS F, UNNI KK. Enchondromatosis: Ollier disease and Maffucci syndrome. In: Fletcher CDM, Unni KK, Mertens F, editors. World Health Organization Classification of Tumors. Pathology and Genetics of Tumors of Soft Tissue and Bone. Lyon: IARC Press, 2002: 356-357.

[34] ROMEO S, HOGENDOORN PC, DEI TOS AP. Benign cartilaginous tumors of bone: from morphology to somatic and germ-line genetics. Adv Anat Pathol 2009; 16: 307-315. http://dx.doi.org/10.1097/PAP.0b013e3181b506a1

[35] HOPYAN S, GOKGOZ N, POON R, GENSURE RC, YU $\mathrm{C}$ et al. A mutant PTH/PTHrP type I receptor in enchondromatosis. Nat Genet 2002; 30: 306-310. http://dx.doi. org/10.1038/ng844

[36] ROZEMAN LB, SANGIORGI L, BRIAIRE-DE BRUIJN IH, MAINIL-VARLET P, BERTONI F et al. Enchondromatosis (Ollier disease, Maffucci syndrome) is not caused by the PTHR1 mutation p.R150C. Hum Mutat 2004; 24: 466-473. http://dx.doi.org/10.1002/humu.20095

[37] AMARY MF, BACSI K, MAGGIANI F, DAMATO S, HALAI D et al. IDH1 and IDH2 mutations are frequent events in central chondrosarcoma and central and periosteal chondromas but not in other mesenchymal tumors. J Pathol 2011; 224: 334 -343. http://dx.doi.org/10.1002/path.2913

[38] BUDDINGH EP, NAUMANN S, NELSON M, NEFFA JR, $\mathrm{BIRCH} \mathrm{N}$ et al. Cytogenetic findings in benign cartilaginous neoplasms. Cancer Genet Cytogenet 2003; 141: 164-168. http://dx.doi.org/10.1016/S0165-4608(02)00726-4
[39] ROZEMAN LB, SZUHAI K, SCHRAGE YM, ROSENBERG C, TANKE HJ et al. Array-comparative genomic hybridization of central chondrosarcoma-Identification of ribosomal protein S6 and cyclin-dependent kinase 4 as candidate target genes for genomic aberrations. Cancer 2006; 107: 380-388. http://dx.doi.org/10.1002/cncr.22001

[40] SCHRAGE YM, LAM S, JOCHEMSEN AG, CLETONJANSEN AM, TAMINIAU AH et al. (2009) Central chondrosarcoma progression is associated with $\mathrm{pRb}$ pathway alterations: CDK4 down-regulation and p16 overexpression inhibit cell growth in vitro. J Cell Mol Med 2009; 3: 2843-2852. http://dx.doi.org/10.1111/j.1582-4934.2008.00406.x

[41] BOVEE JV, HOGENDOORN PC. Molecular pathology of sarcomas: concepts and clinical implications. Virchows Arch 2010; 456: 193-199. http://dx.doi.org/10.1007/s00428-0090828-5

[42] MURPHEY MD, FLEMMING DJ, BOYEA SR, BOJESCUL JA, SWEET DE et al. Enchondroma versus chondrosarcoma in the appendicular skeleton: differentiating features. Radiographics 1998; 18: 1213-1237. http://dx.doi.org/10.1148/radiographic s.18.5.9747616

[43] UHL M, HERGET GW. [Enchondroma. In: Uhl M, Herget GW, editors. Radiologic Diagnosis of Bone Tumors]. [Book in German]. 1st ed. Stuttgart New York: Thieme, 2008: $21-23$

[44] UHL M, HERGET GW. [Chondrosarkoma. In: Uhl M, Herget GW, editors. Radiologic Diagnosis of Bone Tumors]. [Book in German] 1st ed. Stuttgart New York: Thieme, 2008: 32-41

[45] WANG XL, DE BEUCKELEER LH, DE SCHEPPER AM, VAN MARCK E. Low-grade chondrosarcoma vs enchondroma: challenges in diagnosis and management. Eur Radiol 2001; 11: 1054-1057. http://dx.doi.org/10.1007/s003300000651

[46] ALYAS F, JAMES SL, DAVIES AM, SAIFUDDIN A. The role of MR imaging in the diagnostic characterisation of appendicular bone tumors and tumor-like conditions. Eur Radiol 2007; 17: 2675-2686. http://dx.doi.org/10.1007/s00330-007-0597-y

[47] YOO HJ, HONG SH, CHOI JY, MOON KC, KIM HS et al. Differentiating high-grade from low-grade chondrosarcoma with MR imaging. Eur Radiol 2009; 19: 3008-3014. http://dx.doi. org/10.1007/s00330-009-1493-4

[48] BJORNSSON J, MCLEOD RA, UNNI KK, ILSTRUP DM, PRITCHARD DJ. Primary chondrosarcoma of long bones and limb girdles. Cancer 1998; 83: 2105-2119. http://dx.doi. org/10.1002/(SICI) 1097-0142(19981115)83:10<2105::AIDCNCR9>3.0.CO;2-U

[49] LOGIE CI, WALKER EA, FORSBERG JA, POTTER BK, MURPHEY MD. Chondrosarcoma: A Diagnostic Imager's Guide to Decision Making and Patient Management. Semin Musculoskelet Radiol 2013; 17: 101-115. http://dx.doi.org/ 10.1055/s-0033-1342967

[50] CHOI BB, JEE WH, SUNWOO HJ, CHO JH, KIM JY et al. MR differentiation of low-grade chondrosarcoma from enchondroma. Clin Imaging 2013; 37: 542-547. http://dx.doi. org/10.1016/j.clinimag.2012.08.006

[51] MIOT-NOIRAULT E, GOUIN F, VIDAL A, RAPP M, MAUBLANT J et al. First preclinical imaging of primary cartilage neoplasm and its local recurrence using 99mTc-NTP 15-5 
radiotracer. J Nucl Med 2009; 50: 1541-1547. http://dx.doi. org/10.2967/jnumed.108.056721

[52] HOGENDOORN PC; ESMO/EUROBONET WORKING GROUP, ATHANASOU N, BIELACK S, DE ALAVA E, DEI TOS AP, FERRARI S ET AL. Bone sarcomas: ESMO Clinical Practice Guidelines for diagnosis, treatment and followup. Ann Oncol 2010; 21 Suppl 5: 204-213. http://dx.doi. org/10.1093/annonc/mdq223

[53] HUDSON TM, CHEW FS, MANASTER BJ. Radionuclide bone scanning of medullary chondrosarcoma. Am J Roentgenol 1982; 139: 1071-1076. http://dx.doi.org/10.2214/ ajr.139.6.1071

[54] MCLEAN RG, MURRAY IP. Scintigraphic patterns in certain primary malignant bone tumors. Clin Radiol 1984; 35: 379-383. http://dx.doi.org/10.1016/S0009-9260(84)80196-8

[55] WANG K, ALLEN L, FUNG E, CHAN CC, CHAN JC, GRIFFITH JF. Bone scintigraphy in common tumors with osteolytic components. Clin Nucl Med 2005; 30: 655-671. http://dx.doi. org/10.1097/01.rlu.0000178027.20780.95

[56] AOKI J, WATANABE H, SHINOZAKI T, TOKUNAGA M, INOUE $\mathrm{T}$ et al. FDG-PET in differential diagnosis and grading of chondrosarcomas. J Comput Assist Tomogr 1999; 23: 603-608. http://dx.doi.org/10.1097/00004728-19990700000022

[57] BRENNER W, CONRAD EU, EARY JF. FDG PET imaging for grading and prediction of outcome in chondrosarcoma patients. Eur J Nucl Med Mol Imaging 2004; 31: 189-195. http://dx.doi.org/10.1007/s00259-003-1353-4

[58] LEE FY, YU J, CHANG SS, FAWWAZ R, PARISIEN MV. Diagnostic value and limitations of fluorine- 18 fluorodeoxyglucose positron emission tomography for cartilaginous tumors of bone. J Bone Joint Surg [Am] 2004; 86: 2677-2685.

[59] FELDMAN F, VAN HEERTUM R, SAXENA C, PARISIEN M. 18FDG-PET applications for cartilage neoplasms. Skeletal Radiol 2005; 34: 367-374. http://dx.doi.org/10.1007/s00256005-0894-y

[60] FELDMAN F, VANHEERTUM R, SAXENA C. 18Fluorodeoxyglucose positron emission tomography evaluation of benign versus malignant osteochondromas: preliminary observations. J Comput Assist Tomogr 2006; 30: 858-864. http://dx.doi.org/10.1097/01.rct.0000228160.86096.ca

[61] MAKIS W, HICKESON M, LISBONA R. Interesting image. Maffucci syndrome with extraosseous chondrosarcoma imaged with F-18 FDG PET-CT. Clin Nucl Med 2010; 35: 29-31. http://dx.doi.org/10.1097/RLU.0b013e3181c36160
[62] EEFTING D, SCHRAGE YM, GEIRNAERDT MJ, LE CESSIE, TAMINIAU AH et al. Assessment of interobserver variability and histologic parameters to improve reliability in classification and grading of central cartilaginous tumors. Am J Surg Pathol 2009; 33: 50-57. http://dx.doi.org/10.1097/ PAS.0b013e31817eec2b

[63] DELLING G, JOBKE B, BURISCH S, WERNER M. [Cartilage tumors. Classification, conditions for biopsy and histologic characteristics]. [Article in German] Orthopade 2005; 34: 1267-1281. http://dx.doi.org/10.1007/s00132005-0886-6

[64] GELDERBLOM H, HOGENDOORN PC, DIJKSTRA SD, VAN RIJSWIJK CS, KROL AD et al. The clinical approach towards chondrosarcoma. Oncologist 2008; 13: 320-329. http://dx.doi.org/10.1634/theoncologist.2007-0237

[65] EVANS HL, AYALA AG, ROMSDAHL MM. Prognostic factors in chondrosarcoma of bone: A clinicopathologic analysis with emphasis on histologic grading. Cancer 1977; 40: 818-831. http://dx.doi.org/10.1002/1097-0142(197708)40:2<818::AIDCNCR2820400234>3.0.CO;2-B

[66] Skeletal Lesions Interobserver Correlation Among Expert DIAGNOSTICIANS (SLICED) STUDY GROUP. Reliability of Histopathologic and Radiologic Grading of Cartilaginous Neoplasms in Long Bones. J Bone Joint Surg [Am] 2007; 89: 2113-2123. http://dx.doi.org/10.2106/JBJS.F.01530

[67] PIERZ KA, WOMER RB, DORMANS JP. Pediatric bone tumors: osteosarcoma ewing s sarcoma, and chondrosarcoma associated with multiple hereditary osteochondromatosis. J Pediatr Orthop 2001; 21: 412-418. http://dx.doi.org/10.1097/ 01241398-200105000-00028

[68] DONATI D, COLANGELI S, COLANGELI M, DI BELLA C, BRETONI F Surgical treatment of grade I central chondrosarcoma. Clin Orthop Relat Res 2010; 468: 581-589. http://dx.doi.org/10.1007/s11999-009-1056-7

[69] VETH R, SCHREUDER B, VAN BEEM H, PRUSZCZYNSKI $\mathrm{M}, \mathrm{DE}$ ROOY J. Cryosurgery in aggressive, benign, and lowgrade malignant bone tumors. Lancet Oncol 2005; 6: 25-34. http://dx.doi.org/10.1016/S1470-2045(04)01710-3

[70] SPRINGFIELD DS, GEBHARDT MC, MC GUIRE MH. Chondrosarcoma: a review. J. Bone Joint Surg [Am] 1996; 78: 141-149.

[71] RIEDEL RF, LARRIER N, DODD L, KIRSCH D, MARTINEZ $S$ et al. The clinical management of chondrosarcoma. Curr Treat Options Oncol 2009; 10: 94-106. http://dx.doi. org/10.1007/s11864-009-0088-2 